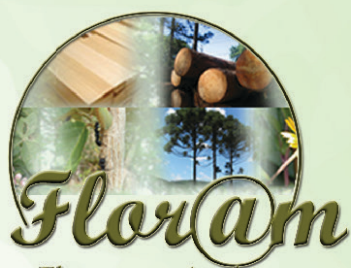

Floresta e Ambiente
Floresta e Ambiente 2019; 26(Spec No 2): e20180436 https://doi.org/10.1590/2179-8087.043618

ISSN 2179-8087 (online)

$\cos ^{2}$

Original Article

\title{
Elementary, Chemical and Energy Characteristics of Brazil Nuts Waste (Bertholletia excelsa) in the State of Pará
}

\author{
Renata Ingrid Machado Leandro ${ }^{1}$ (D), Jesomi Jonatan da Costa Abreu ${ }^{1}$ (D), \\ Cleibiane da Silva Martins² (D), Iêdo Souza Santos ${ }^{3}$ (D), Maria Lucia Bianchi ${ }^{4}$ (D), \\ João Rodrigo Coimbra Nobre ${ }^{3}$ \\ ${ }^{1}$ Universidade Federal de Santa Maria - UFSM, Santa Maria/RS, Brasil \\ ${ }^{2}$ Universidade do Estado de Santa Catarina - UDESC, Lages/SC, Brasil \\ ${ }^{3}$ Departamento de Tecnologia da Madeira, Universidade do Estado do Pará - UEPA, Paragominas/PA, Brasil \\ ${ }^{4}$ Universidade Federal de Lavras - UFLA, Lavras/MG, Brasil
}

\begin{abstract}
This study aimed to determine the chemical and energetic composition of Brazil nut waste in the city of Castanhal-PA. Some of the material was crushed, sifted and stored for acclimatization and analysis. Molecular and immediate chemical analyses were performed on the raw material according to NBR standards. Another part was charred in Muffle furnace, with heating rate of $1.67{ }^{\circ} \mathrm{C}$.min- 1 and temperature of $450{ }^{\circ} \mathrm{C}$ for 60 minutes. For biomass, $55.76 \%$ of lignin and $2.61 \%$ of minerals were found. Means of $65.67 \%$ for volatiles were also found; $2.08 \%$ of ashes and $21.64 \%$ of fixed carbon. In the elementary, means of $53.54 \%$ of carbon and $0.11 \%$ of sulfur were found. For charcoal, $25.81 \%$ of volatiles were found; $1.76 \%$ of ashes and $67.50 \%$ of fixed carbon. Residues have high levels of lignin, fixed carbon and low ash contents, demonstrating potential for direct burning for energy, charcoal, activated carbon and biochar.
\end{abstract}

Keywords: biomass, lignin, charcoal, carbon. 


\section{INTRODUCTION}

Biomass consists of organic material of animal or vegetable origin, and is considered an alternative source of energy. According to Werther et al. (2000) and Saini et al. (2015), agricultural residues present high energy potential, since after carbonization, biomass transforms into charcoal.

Brazil is considered as one of the largest agricultural producers, consequently generating large amounts of waste, which has potential for bioenergy (Vieira et al., 2012; Scatolino et al., 2018). Among these agricultural products, Brazil nuts, known as Bertholletia excelsa species, are one of the main products exported from the Amazon (Lorini et al., 2018).

Brazil nut belongs to family Lecythidaceae and grows in a wide area of South America (Brito et al., 2010), mainly in the region of the State of Pará, Brazil. "Castanheira do Pará", the name given in Brazil to this tree, can be found in the Brazilian Amazon, and in countries like Peru, Colombia, Venezuela and Ecuador. The tree is large, and can reach height of $50 \mathrm{~m}$ or more (Melo et al., 2018). The fruit is a large capsule, known as a hedgehog, within each hedge there may be about 8-26 "chestnut" with their own individual shell. One tree can produce about 300 or more of these hedgehogs with fruits (Kainer et al., 2006). The seed core contains $63-70 \%$ oil, which can be used to make soap and $17 \%$ of protein (Chunhieng et al., 2008).

Yearly, thousands of tons of Brazil nuts are exported (Bonelli et al., 2001; Homma, 2004). In 2010, production increased by $7.7 \%$, with a trend of linear growth in the last three years (Silva et al., 2013). This variation is due to the great demand for the product, mainly by companies related to foreign trade.

It is estimated that for each ton of clean chestnut, 1.4 tons of residues are produced, consisting of bark and the so-called hedgehog, the chestnut fruit. Thus, the total of shells and hedgehogs generated exceeds 56 thousand tons. The aim of this work was to determine the elementary, chemical and energetic composition to indicate the potential use of Brazil nut biomass waste.

\section{MATERIAL AND METHODS}

Agroindustrial Brazil nut wastes (Bertholletia excelsa) were collected in the municipality of Castanhal, located in the northeastern region of the State of Pará.
These residues are constituted of shells and urchins originated from processing to obtain chestnut almonds.

Some of the fresh material was stored for later carbonization. The other part was packed in sealed and identified plastic bags. Then, the biomass was crushed and sieved in a set of sieves with grain size of 40, 60, 100, 200 and 270 mesh to carry out analyses. The granulometrically classified materials were stored in an air conditioning room, with temperature conditions of $20 \pm 2{ }^{\circ} \mathrm{C}$ and humidity of $65 \pm 3 \%$, until reaching constant mass, with mean humidity of $12 \%$.

In the chemical analyses, ABNT NBR 7989/2010 (ABNT, 2010a) was used for lignin quantification, ABNT NBR 14853/2010 (ABNT, 2010b) for total secondary components (extractives) and ABNT NBR 13999/2003 (ABNT, 2003) to determine inorganic constituents (minerals) of the residue. The holocellulose content was determined by difference in relation to the other chemical constituents as total extractives, lignin and minerals.

For elementary analysis (CHNS), the fraction that passed through the 200-mesh sieve was used and was retained in the 270 mesh, indicated for the follow-up of the analysis. Carbon, hydrogen, nitrogen, sulfur and oxygen (by difference) contents were determined in an Elemental universal analyzer, model Vario Micro Cube. The analyzer uses, as drag and ignition gases, helium and oxygen, respectively. The 2-mg and three replicate samples were packed in tin capsules and completely incinerated at $1200^{\circ} \mathrm{C}$.

The chemical characterization of charcoals and biomass was carried out according to procedures and standards described by Moulin et al. (2017), taking into account adaptation of heating values. All chemical analyses were carried out in triplicate to calculate the mean values, standard deviation and variation coefficient, with values being obtained in the form of descriptive statistics.

For the production of vegetal coals, fresh material with mean humidity of $12 \%$, was used for all residues. The charcoal was produced in a Muffle-type furnace adapted to this function, with heating rate of $1.67^{\circ} \mathrm{C} . \mathrm{min}^{-1}$, at temperature of $450^{\circ} \mathrm{C}$, with residence time of 60 minutes. Cooling occurred naturally and gradually after the furnace reached the final carbonization temperature and time. The choice of carbonization conditions was based on the methodology described by Nobre et al. 
(2015), in which Amazonia wood wastes were used to produce activated carbon.

\section{RESULTS AND DISCUSSION}

The results obtained in the chemical and elementary biomass analyses are described in Tables 1, 2 and 3.

For the chemical composition, biomass exhibited mean values of $55.76 \%$ of lignin, $4.54 \%$ of extractives, $2.61 \%$ of minerals and $37.09 \%$ of holocellulose. Among the results, it is worth highlighting lignin, which presented high value, favoring the production of activated carbon, since it is the substance most resistant to thermal degradation, when compared to cellulose and hemicelluloses.

According to Brito \& Barrichelo (1977) and Santos et al. (2016) high lignin contents may be correlated with higher fixed carbon content, volatile substances and consequently higher gravimetric coal yield.

The values obtained for the content of volatile materials, fixed carbon and ash (immediate chemical composition), are shown in Table 2.
These values are close to those found by Netto et al. (2006), who obtained $71.04 \%$ of volatile materials, $1.88 \%$ of ashes and $27.07 \%$ of fixed carbon. The low ash content is a positive factor for the production of activated carbon, considering that mineral components cause an unfavorable effect on the adsorption process, preferentially adsorbing water, due to the hydrophilic character (Moreno-Castilla, 2004). Raw materials with higher carbon content and lower ash content may be considered more suitable for the production of activated carbon (Chen et al., 2013).

The amount of fixed carbon, ash and volatiles, directly affect the quality of activated carbon (Melo et al., 2015; Apaydin-Varol \& Erülken, 2015). In addition, it is possible to estimate the yield of coal to be obtained (Oliveira et al., 2010; Schröder et al., 2007).

Studies by Bonelli et al. (2001) indicate that Brazil nut residues have characteristics that demonstrate their capacity to be transformed into charcoal and consequently activated carbon, with immediate chemical composition of $76.1 \%$ of volatile materials, $22.2 \%$ of fixed carbon and only $1.7 \%$ of ashes.

Table 1. Mean chemical composition, standard deviation (SD) and variation coefficient (VC) values of Brazil nut residues.

\begin{tabular}{ccccc}
$\begin{array}{c}\text { Chemical } \\
\text { composition }\end{array}$ & Lignin (\%) & Extracts (\%) & Minerals (\%) & Holocellulose* (\%) $^{*}$ \\
Mean & 55.76 & 4.54 & 2.61 & 37.09 \\
SD & 6.64 & 0.28 & 0.17 & 0.06 \\
VC & 11.91 & 6.35 & 6.81 & 0.20 \\
\hline
\end{tabular}

*Values obtained by difference; $\mathrm{SD}=$ standard deviation; $\mathrm{VC}=$ variation coefficient.

Table 2. Immediate chemical composition for Brazil nut biomass.

\begin{tabular}{ccccc}
$\begin{array}{c}\text { Chemical } \\
\text { composition }\end{array}$ & Moisture (\%) & Volatile (\%) & Ashes (\%) & Fixed Carbon* $\left.{ }^{*} \%\right)$ \\
Mean & 10.61 & 65.67 & 2.08 & 21.64 \\
SD & 0.14 & 0.30 & 0.04 & 0.29 \\
VC & 1.41 & 0.46 & 2.21 & 0.90 \\
\hline
\end{tabular}

${ }^{*}$ Values obtained by difference between the other constituents; $\mathrm{SD}=$ standard deviation; $\mathrm{CV}=$ coefficient of variation.

Table 3. Mean elementary analysis, standard deviation (SD) and variation coefficient (VC) values for Brazil nut biomass.

\begin{tabular}{ccccccc} 
Elements & $\mathbf{C ~ ( \% )}$ & $\mathbf{H}(\%)$ & $\mathbf{N}(\%)$ & $\mathbf{S ~ ( \% )}$ & $-\mathbf{O}(\%)^{*}$ & $\mathbf{O} / \mathbf{C}$ \\
\hline Mean & 53.54 & 5.69 & 1.57 & 0.11 & 37.01 & 0.69 \\
SD & 0.81 & 0.07 & 0.05 & 0.01 & 0.93 & 0.03 \\
VC & 1.52 & 1.31 & 2.87 & 7.30 & 2.52 & 4.00 \\
\hline
\end{tabular}

*Values obtained by difference between the other constituents, discounting the amount of minerals of the immediate composition (Table 2); SD = standard deviation; $\mathrm{VC}=$ variation coefficient. 
Table 4. Immediate chemical composition of produced charcoal.

\begin{tabular}{ccccc|}
$\begin{array}{c}\text { Chemical } \\
\text { composition }\end{array}$ & Moisture (\%) & Volatiles (\%) & Ashes (\%) & Fixed carbon (\%)* \\
\hline Mean & 4.93 & 25.81 & 1.76 & 67.50 \\
SD & 0.25 & 1.07 & 0.28 & 0.98 \\
VC & 0.05 & 0.04 & 0.16 & 0.01 \\
\hline
\end{tabular}

${ }^{*}$ Values obtained by difference between the other constituents; $\mathrm{SD}=$ standard deviation; $\mathrm{VC}=$ variation coefficient.

Table 5. Mean elementary analysis, standard deviation (SD) and variation coefficient (VC) values of carbons at carbonization temperature of $450^{\circ} \mathrm{C}$.

\begin{tabular}{cccccrc} 
Elements & $\mathbf{C ~ ( \% )}$ & $\mathbf{H}(\%)$ & $\mathbf{N}(\%)$ & $\mathbf{S}(\%)$ & $-\mathbf{O}(\%)^{\star}$ & $\mathbf{O} / \mathbf{C}$ \\
\hline Mean & 72.50 & 3.46 & 1.94 & 0.16 & 19.86 & 0.27 \\
SD & 1.27 & 0.07 & 0.01 & 0.00 & 1.35 & 0.02 \\
VC & 1.75 & 1.94 & 0.73 & 2.72 & 6.80 & 8.54 \\
\hline
\end{tabular}

${ }^{*}$ Values obtained by difference between the other constituents, discounting the amount of minerals of the immediate composition (Table 2); SD = standard deviation; $\mathrm{VC}=$ variation coefficient.

These authors also presented the elementary chemical characteristics of this material, which corroborate the suggestion for use as precursors in the production of charcoal and activated carbon, having $50.0 \%$ of carbon, $5.8 \%$ of hydrogen, $0.7 \%$ of nitrogen and $43.5 \%$ of oxygen.

The values obtained for carbon, hydrogen, nitrogen and sulfur contents found for the four species through elementary analysis are shown in Table 3.

In the immediate chemical composition of charcoal, means of $4.93 \%$ of moisture, $25.81 \%$ of volatiles, $1.76 \%$ of ashes and $67.50 \%$ of fixed carbon were found, in addition to gravimetric yield of $41.67 \%$, standard deviation of 1.20 and variation coefficient equal to 2.88. This occurs because the residue has a high content of lignin and carbon, which gives more resistance to the thermal degradation of the material during the carbonization process. Another relevant factor is the oxygen content, which also contributes to coal yield. The lower oxygen content allows for less combustion of the material during the carbonization process, because combustion occurs or is increased due to the amount of oxygen present in the material to be charred and in the furnace where it will be pyrolysed.

The values found for the chemical composition of charcoal produced from Brazil nuts residual biomass are described in Table 4.

Nogueira et al. (2014) show that charcoal produced from chestnut residues has the necessary amounts to be used as a precursor of activated carbon, finding values for immediate chemical analysis with $4.71 \%$ of humidity, $20.79 \%$ of volatile materials, $0.87 \%$ of ashes and $78.33 \%$ of fixed carbon.

Elementary analysis (CHNS-O) values for coal produced at $450^{\circ} \mathrm{C}$ can be seen in Table 5 .

It was observed that, in coal, carbon contents are higher and hydrogen contents are lower when compared to original biomasses (Table 3). Pyrolysis allows obtaining product with high carbon content due to the volatilization of hydrogen, oxygen and nitrogen containing compounds (Sekirifa et al., 2013).

\section{CONCLUSION}

The analyses performed showed the energy potential of Brazil nuts residues, and results showed high levels of lignin, fixed carbon, volatile substances and low ash content, determining potential for the use of Brazil nut biomass for direct burning, production of good quality activated carbon and also biochar.

\section{ACKNOWLEDGEMENTS}

To the Federal University of Lavras, to the Graduate Program in Wood Science and Technology, to the University of the State of Pará and to the Research Group Wood Science, Innovation and Technology in the Amazon for the opportunity to carry out this work. 


\section{SUBMISSION STATUS}

Received: 26 nov., 2018

Accepted: 13 dec., 2018

\section{CORRESPONDENCE TO}

\section{João Rodrigo Coimbra Nobre}

Universidade do Estado do Pará - UEPA, Rodovia PA-124, s/n, Bairro Angelim, CEP 68625-000, Paragominas, PA, Brasil e-mail: rodrigonobre@uepa.br, rodrigonobre@ hotmail.com.br

\section{REFERENCES}

Apaydin-Varol E, Erülken Y. A study on the porosity development for biomass based carbonaceous materials. Journal of the Taiwan Institute of Chemical Engineers 2015; 54: 37-44. http://dx.doi.org/10.1016/j.jtice.2015.03.003.

Associação Brasileira de Normas Técnicas - ABNT. NBR13999: determinação do resíduo (cinza) após a incineração a $525^{\circ} \mathrm{C}$. Rio de Janeiro: ABNT; 2003.

Associação Brasileira de Normas Técnicas - ABNT. NBR-7989: polpa celulósica e madeira: determinação de lignina insolúvel em ácido. Rio de Janeiro: ABNT; 2010a.

Associação Brasileira de Normas Técnicas - ABNT. NBR14853: determinação do material solúvel em etanol-tolueno e em diclorometano e acetona. Rio de Janeiro: ABNT; 2010b.

Bonelli PR, Della Rocca PA, Cerrella EG, Cukierman AL. Effect of pyrolysis temperature on composition, surface properties and thermal degradation of Brazil nut shells. Bioresource Technology 2001; 76(1): 15-22. http://dx.doi. org/10.1016/S0960-8524(00)00085-7. PMid:11315805.

Brito JO, Barrichelo LEG. Correlações entre características físicas e químicas da madeira e a produção de carvão vegetal: densidade e teor de lignina da madeira de eucalipto. Revista IPEF [online] 1977; 14: 9-20 [cited 2018 Nov 26]. Available from: http://www.ipef.br/publicacoes/scientia/ nr14/cap01.pdf

Brito SMO, Andrade HMC, Soares LF, Azevedo RP. Brazil nut shells as a new biosorbent to remove methylene blue and indigo carmine from aqueous solutions. Journal of Hazardous Materials 2010; 174(1-3): 84-92. http://dx.doi. org/10.1016/j.jhazmat.2009.09.020. PMid:19781853.

Chen W, Liu X, He RL, Lin T, Zeng QF, Wang XG. Activated carbon powders from wool fibers. Powder Technology 2013; 234: 76-83. http://dx.doi.org/10.1016/j. powtec.2012.09.026.

Chunhieng T, Hafidi A, Pioch D, Brochier J, Didier M. Detailed study of Brazil nut (Bertholletia excelsa) oil microcompounds: phospholipids, tocopherols and sterols. Journal of the Brazilian Chemical Society 2008; 19(7): 1374-1380. http://dx.doi.org/10.1590/S0103-50532008000700021.

Homma AKO. Cemitério das Castanheiras. Ciência Hoje 2004; 34(202): 60-63.

Kainer KA, Wadt LHO, Gomes-Silva MAP, Capanu M. Liana loads and their association with Bertholletia excelsa fruit and nut production, diameter growth and crown attributes. Journal of Tropical Ecology 2006; 22(2): 147-154. http://dx.doi.org/10.1017/S0266467405002981.

Lorini A, Wobeto C, Rosa CCB, Hatem TA, Botelho SCC. Influence of packaging on the quality of Brazil nuts. Acta Amazonica 2018; 48(4): 368-372. http://dx.doi. org/10.1590/1809-4392201701772.

Melo SS, Diniz JEM, Guimarães JH, Costa JS, Brazil DSB, Morais SSS et al. Production and characterization of absorbent heat from the bark of residual Brazil nut bark (Bertholletia excelsa L.). Chemistry Central Journal 2015; 36(9): 1-9. http://dx.doi.org/10.1186/s13065-015-0114-3. PMid:26150893.

Melo VF, Batista AH, Barbosa JZ, Barbeiro L, Gomes R, Dultra MTM. Soil quality and reforestation of the Brazil nut tree (Bertholletia excelsa Bonpl.) after laterite-type bauxite mining in the Brazilian Amazon forest. Ecological Engineering 2018; 125: 111-118. http://dx.doi.org/10.1016/j. ecoleng.2018.10.016.

Moreno-Castilla C. Adsorption of organic molecules from aqueous solutions on carbon materials. Carbon 2004; 42(1): 83-94. http://dx.doi.org/10.1016/j.carbon.2003.09.022.

Moulin JC, Nobre JRC, Castro JP, Trugilho PF, Arantes MDC. Effect of extractives and carbonization temperature on energy characteristics of wood waste in Amazon rainforest. Cerne 2017; 23(2): 209-218. http://dx.doi.or $\mathrm{g} / 10.1590 / 01047760201723022216$.

Netto GBF, Oliveira AGP, Coutinho HWM, Nogueira MFM, Rendeiro G. Caracterização energética de biomassas amazônicas. In: Anais do $6^{\circ}$ Encontro de Energia no Meio Rural [online]; 2006; Campinas. Campinas: UNICAMP; 2006 [cited 2018 Nov 26]. Available from: http://www. proceedings.scielo.br/pdf/agrener/n6v1/035.pdf

Nobre JRC, Castro JP, Motta JP, Bianchi ML, Trugilho PF, Borges WMS et al. Activated carbon production of the wood residue of the Amazonian area. Scientia Forestalis 2015; 43(108): 895-906. http://dx.doi.org/10.18671/scifor. v43n108.14.

Nogueira RM, Ruffato S, Carneiro JS, Pires EM, Álvare VS. Evaluation of the carbonization of the Brazil nut urchin in a drum type oven. Scientific Electronic Archives [online] 2014; 2014(6): 7-17 [cited 2018 Nov 26]. Available from: https://ainfo.cnptia.embrapa.br/digital/bitstream/ item/114745/1/25369.pdf

Oliveira AC, Carneiro ACO, Vital BR, Almeida W, Pereira BLC, Cardoso MT. Quality parameters of Eucalyptus 
pellita F. Muell. Wood and charcoal. Scientia Forestalis 2010; 87(38): 431-439.

Saini JK, Saini R, Tewari L. Lignocellulosic agriculture wastes as biomass feedstocks for second-generation bioethanol production: concepts and recent developments. 3 Biotech 2015; 5(4): 337-353. http://dx.doi.org/10.1007/ s13205-014-0246-5. PMid:28324547.

Santos RC, Carneiro ADCO, Vital BR, Castro RVO, Vidaurre GB, Trugilho PF et al. Effect of poperties chemical and siringil/guaiacil relation wood clones of eucalytus in the production of charcoal. Ciência Florestal 2016; 26(2): 657-669. http://dx.doi.org/10.5902/1980509822765.

Scatolino MV, Cabral LF No, Protásio TP, Carneiro ACO, Andrade CR, Guimarães JB Jr et al. Options for generation of sustainable energy: production of pellets based on combinations between lignocellulosic biomasses. Waste and Biomass Valorization 2018; 9(3): 479-489. http:// dx.doi.org/10.1007/s12649-017-0010-2.

Schröder E, Thomauske K, Weber C, Hornung A, Tumiatti $\mathrm{V}$. Experiments on the generation of activated carbon from biomass. Journal of Analytical and Applied Pyrolysis
2007; 79(1-2): 106-111. http://dx.doi.org/10.1016/j. jaap.2006.10.015.

Sekirifa ML, Hadj-Mahammed M, Pallier S, Baameur L, Richard D, Al-Dujaili AH. Preparation and characterization of an activated carbon from a variety of stones by physical activation with carbon dioxide. Journal of Analytical and Applied Pyrolysis 2013; 99: 155-160. http://dx.doi. org/10.1016/j.jaap.2012.10.007.

Silva AA, Santos MKV, Gama JRV, Noce R, Leão S. Potential of Brazil nut extraction to generate income in the communities of the Lower Amazon mesoregion, Brazil. Floresta e Ambiente 2013; 20(4): 500-509. http:// dx.doi.org/10.4322/floram.2013.046.

Vieira AC, Souza NM, Bariccatti RA, Siqueira JAC, Eduardo C, Nogueira C. Characterization of rice husk for power generation. Varia Scientia Agrárias 2012; 3(1): 51-57.

Werther J, Saenger M, Hartge EU, Ogada T, Siagi Z. Combustion of agricultural residues. Progress in Energy and Combustion Science 2000; 26(1): 1-27. http://dx.doi. org/10.1016/S0360-1285(99)00005-2. 